\title{
Progesterone levels on the human chorionic gonadotropin trigger day affect the pregnancy rates for embryos transferred at different stages of development in both general and selected IVF/ICSI populations
}

P. Merviel ${ }^{*}$, S. Bouée, A. S. Jacamon, J. J. Chabaud, M. T. Le Martelot, S. Roche, C. Rince, H. Drapier, A. Perrin and D. Beauvillard

\begin{abstract}
Background: Two meta-analyses have shown that pregnancy and birth rates are significantly higher after blastocyst transfer than after cleaved embryo transfer. Other studies have revealed that a serum progesterone level $>1.5 \mathrm{ng} / \mathrm{ml}$ on the trigger day is responsible for premature luteinization and is associated with a low pregnancy rate. The objectives of this retrospective study were to determine whether blastocyst transfer gave higher pregnancy rates than cleaved embryo transfer at day 3 in both the general and selected IVF/ICSI populations, and whether the serum progesterone level influenced the pregnancy rate.
\end{abstract}

Method: We studied IVF/ICSI cycles with GnRH antagonist - FSH/hMG protocols in a general population $(n=1210)$ and a selected "top cycle" population $(n=677)$, after blastocyst transfer on day 5 or cleaved embryo transfer on day 3. The selected couples had to meet the following criteria: female age $<35$, first or second cycle, and one or two embryos transferred. We recorded predictive factors for pregnancy and calculated the progesterone to oocyte index (POI), the progesterone:estradiol ratio (P:E2 ratio), and the progesterone to follicle (> $14 \mathrm{~mm}$ ) index (PFI).

Results: In the general population, the clinical pregnancy rate was significantly higher after blastocyst transfer (33.3\%) than after cleaved embryo transfer (25.3\%; $p<0.01$ ); the same was true for the birth rate (32.1 and 22.8\%, respectively, $p<0.01$ ). The differences between blastocyst and embryo transfer groups were not significant in the selected population (respectively $35.7 \%$ vs. $35.8 \%$ for the clinical pregnancy rate, and 33.9 and $34.9 \%$ for the birth rate). The serum progesterone levels on the eve of the trigger day and on the day itself were significantly lower in the pregnant women $(p<0.01)$. We found a serum progesterone threshold of $0.9 \mathrm{ng} / \mathrm{ml}$, as also reported by other researchers. The POI and the PFI appear to have predictive value for cleaved embryos transfers.

(Continued on next page)

\footnotetext{
* Correspondence: philippe.merviel@chu-brest.fr

Department of Gynecology, Obstetrics and Reproductive Medicine, Brest

University Hospital, 2 avenue Foch, F-29200 Brest, France
}

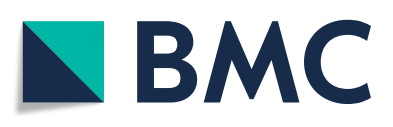

(c) The Author(s). 2021 Open Access This article is licensed under a Creative Commons Attribution 4.0 International License, which permits use, sharing, adaptation, distribution and reproduction in any medium or format, as long as you give appropriate credit to the original author(s) and the source, provide a link to the Creative Commons licence, and indicate if changes were made. The images or other third party material in this article are included in the article's Creative Commons licence, unless indicated otherwise in a credit line to the material. If material is not included in the article's Creative Commons licence and your intended use is not permitted by statutory regulation or exceeds the permitted use, you will need to obtain permission directly from the copyright holder. To view a copy of this licence, visit http://creativecommons.org/licenses/by/4.0/ The Creative Commons Public Domain Dedication waiver (http://creativecommons.org/publicdomain/zero/1.0/) applies to the data made available in this article, unless otherwise stated in a credit line to the data. 
(Continued from previous page)

Conclusions: Blastocyst transfers were associated with higher clinical pregnancy and birth rates than cleaved embryo transfers in a general population but not in a selected population. The serum progesterone levels on the eve of the trigger day and on the day itself predicted the likelihood of pregnancy.

Keywords: IVF/ICSI, Pregnancy, Progesterone, Blastocyst, Cleaved embryo

\section{Introduction}

One in six couples will consult for infertility, defined as failure to achieve a clinical pregnancy after 12 months or more of regular unprotected sexual intercourse [1]. In this setting, in vitro fertilization/intracytoplasmic sperm injection (IVF/ICSI) is one possible treatment option for achieving a live birth. Even though IVF/ICSI has enabled the birth of over 8 million children since 1978, the pregnancy rates per embryo transfer vary from 10 to $50 \%$ [2]. Predictive factors for pregnancy include the woman's age, the cycle rank, and the number of good-quality embryos [3]. In 2013, we defined a select group of "top" IVF/ICSI cycles, with the following characteristics: the first or second IVF/ICSI cycle, female age under 35, and the transfer of no more than two top embryos $[4,5]$.

Initially, IVF/ICSI was based on cleaved embryo transfer on day 2 (D2) or day 3 (D3). However, progress in in vitro culture and embryo cryopreservation has made it possible to envisage blastocyst transfer on day (D5) or day 6 (D6). Blastocyst transfer has several advantages: decreased uterine exposure to very high serum estradiol levels [6], better synchronization between embryonic development and endometrial maturation, the selection of embryos that progress to a blastocyst stage, and a decrease in uterine contractions [7]. Several meta-analyses have shown that blastocyst transfer is associated with significantly higher clinical pregnancy and birth rates $[8$, 9]. In some cases, however, cleaved embryos do not develop into blastocysts in vitro, even though the couple may have achieved embryo implantation previously.

The luteal maturation of the endometrium (luteinization) required for embryo implantation depends on the estrogenic effect and adequate progesterone secretion as soon as the ovulatory LH peak has been triggered [10]. In some women in IVF/ICSI, the serum progesterone level peaks too early; this results in premature luteinization and an implantation window that opens (but also closes) earlier. The administration of a gonadotropin releasing hormone $(\mathrm{GnRH})$ antagonist is intended to limit the risk of premature luteinization in IVF/ICSI cycles. A key question in cases of premature luteinization is whether the embryo's development stage at the time of transfer influences the pregnancy rate. We therefore assessed GnRH antagonist-gonadotropin IVF/ICSI protocols in a general population and a selected population ("top cycles"). The study's objectives were to (i) measure the pregnancy rates after the transfer of blastocysts or cleaved embryos in these two populations, and (ii) determine whether the serum progesterone level just before the trigger influences the likelihood of pregnancy.

\section{Material and methods}

All the couples enrolled in the IVF/ICSI programs studied here had undergone an infertility assessment. For the women, this included hormone blood tests on the second or third day of the menstrual cycle (including serum levels of FSH, LH, estradiol - E2, prolactin, and anti-Müllerian hormone - AMH), an ultrasound scan of the pelvis (with determination of the antral follicle count), and hysterosalpingography (followed by coelioscopy and/or hysteroscopy, if the results were abnormal). For the men, the assessment included a semen analysis and a sperm motility test. All the hormone blood tests and sperm examinations were performed in the same laboratory.

The main inclusion criteria were physician-diagnosed infertility, female age 18 to 42 , male age 18 to 59 , and written consent to infertility treatment. Given that the couples had already consented to exploitation of their personal medical data for research purposes, and in line with the French legislation on analyses of routine medical care, approval by an independent ethics committee was not required. The main exclusion criteria were ovarian insufficiency (antral follicle count $<5$, AMH $<$ $0.5 \mathrm{ng} / \mathrm{ml}$, and/or FSH $>15 \mathrm{IU} / \mathrm{l})$, severe abnormality of the uterine cavity (synechiae or diffuse adenomyosis), irreversible azoospermia (according to a testicular biopsy), and globozoospermia. We excluded cycles involving donor gametes or donor embryos.

In a controlled ovarian stimulation protocol with a $\mathrm{GnRH}$ antagonist, stimulation was initiated on D2 of the cycle with FSH (Fostimon', Genevrier, Sophia-Antipolis, France/ Gonal- $F^{\circ}$, Merck, Lyon, France/ Puregon ${ }^{\circ}, \mathrm{MSD}$, Levallois-Perret, France) or hMG (Menopur, Ferring SAS, St Prex, Switzerland), together with $0.25 \mathrm{mg}$ per day ganirelix (Orgalutran ${ }^{\circ}$, MSD, Levallois-Perret, France) when the follicle size exceeded $14 \mathrm{~mm}$ or the estradiol (E2) level was over $400 \mathrm{pg} / \mathrm{mL}$. The gonadotropin doses were adjusted after the first ultrasound examination and the E2 and LH assays on gonadotropin D5. When at least three follicles had reached a diameter $\geq$ $17 \mathrm{~mm}$, a dose of $250 \mu \mathrm{g}$ of recombinant human 
chorionic gonadotropin (Ovitrelle ${ }^{\circ}$, Merck, Lyon, France) was administered. Oocytes $(\mathrm{O})$ were retrieved $35 \mathrm{~h}$ after hCG administration.

Luteal phase supplementation consisted of $400 \mathrm{mg}$ per day of intravaginal micronized progesterone (Utrogestan ${ }^{\circ}$; Besins International, Paris, France) from the evening of oocyte retrieval until the $\beta$-hCG assay two weeks later. Our center applies a freeze-all strategy if (i) the serum progesterone level on the hCG trigger day exceeds $1.5 \mathrm{ng} /$ $\mathrm{ml}$, (ii) ovarian hyperstimulation ( $>20$ follicles) is observed on ultrasound or the serum estradiol level exceeds 3500 $\mathrm{pg} / \mathrm{ml}$ on the hCG trigger day, or (iii) spermatozoids are not available on the day of the oocyte retrieval.

For the ICSI procedure, the corona radiata as removed mechanically under a dissecting microscope, and the cumulus was exposed to $0.5 \%$ hyaluronidase (Sigma-Aldrich, St. Louis, MO, USA) for $30 \mathrm{~s}$. The partner's sperm was analyzed according to the WHO classification [11] and then prepared for ICSI. The oocytes were examined after $18 \mathrm{~h}$ of incubation at $37^{\circ} \mathrm{C}$ in a humidified atmosphere with $5 \%$ $\mathrm{CO}_{2}$; the presence of two pronuclei (2PN) was a sign of fertilization. The fertilization rate was defined as the ratio between the number of fertilized (2PN) oocytes and the number of mature (metaphase II) oocytes. The resulting embryos were cultured up until D3 or D5. The cleavage rate corresponds to the ratio between D3 cleaved embryos and mature oocytes. Moreover, we recorded the embryos' frequency of progression from D3 to D5 (i.e. the blastocyst/embryo ratio). A suitable cleaved embryo on D3 was defined as the presence of 8 to 14 uniform-size blastomeres, a fragmentation rate below $50 \%$, and the absence of multinucleation [12]. Blastocysts were classified according to Gardner's criteria [13]. Adequate blastocyst quality on D5 was defined as stage B3 to B6, an inner cell mass, and fragmentation types $\mathrm{AA}, \mathrm{AB}, \mathrm{BA}, \mathrm{BB}$ and (very occasionally) $\mathrm{CA}$ and $\mathrm{CB}$, and the absence of multinucleation. Embryos were transferred alternately on either D3 or D5 because the study's objective was to evaluate the pregnancy rate under these two circumstances. One or two of the best embryos were transferred in utero using a Frydman catheter (CCD Laboratories, Paris, France), and other good-quality embryos were cryopreserved.

Clinical pregnancy was confirmed by ultrasound and a $\beta$-hCG level above 1000 IU/L 6 to 8 weeks after embryo transfer, and the clinical pregnancy rate was calculated relative to the number of cycles with a transfer. An ongoing pregnancy was defined as a pregnancy after more than 12 weeks of amenorrhea (WA). The miscarriage rate was calculated with regard to the number of clinical pregnancies after the first trimester, and a miscarriage was classified as pregnancy loss before 12 WA. A live birth was defined as a healthy child birth later than 22 week of gestation. Each couple assessed in the present study went through a single ICSI cycle.
The study's primary outcome measure was the clinical pregnancy, ongoing pregnancy and live birth rates for cleaved embryo transfers on D3 vs. blastocyst transfers on D5. Starting from the general population, we selected a subpopulation of "top cycles", as described previously $[4,5]$. In the "top cycle", the couples were in their first or second IVF/ICSI cycle, the women was under the age of 35 , and one or two top embryos were transferred. In each group, we looked for predictors of pregnancy and analyzed the pregnancy rates above and below the progesterone threshold of $0.9 \mathrm{ng} / \mathrm{ml}$ defined by Venetis et al. [14]. The idea to study a selected population ("top cycle") is to check pregnancy rates by embryo stage and the impact of the progesterone levels in a population of good prognosis. In particular, do the young age of women, the notion of a first or second cycle and the good quality of the embryo change the results observed in the general population.

Based on the serum progesterone (P) level on the trigger day, we calculated three ratios already described in the literature, which may explain the impact of the progesterone on the occurrence of pregnancy: $\mathrm{P}$ (in $\mathrm{ng} / \mathrm{ml}$ ) divided by the number of oocytes retrieved $(\mathrm{O})$, so called as progesterone to oocyte index (POI) [15], P (in pg/ml) divided by the serum $\mathrm{E} 2$ level (in $\mathrm{pg} / \mathrm{ml}$ ) on the trigger day (P:E2 ratio [16];), and $\mathrm{P}$ (in $\mathrm{nM}$ ) divided by the number of follicles $>14 \mathrm{~mm}$ (a ratio referred to as the progesterone to follicle index (PFI) in the literature [17]). A progesterone concentration of $1 \mathrm{ng} / \mathrm{ml}$ corresponds to $3.18 \mathrm{nM}$.

\section{Statistical analysis}

Continuous variables were expressed as the mean \pm standard deviation (SD) (for normally distributed data) or the median [interquartile range]. Categorical variables were expressed as the frequency (percentage). Differences between groups were probed with Student's t test or Pearson's chi-squared test. All analyses were performed using Microsoft ${ }^{\circ}$ Excel (Microsoft Corporation, Redmond, WA, USA) and the XLSTAT ${ }^{\circ}$ add-on (Addinsoft, Paris, France). The threshold for statistical significance was set to $p<0.05$. Given that we extracted data from electronic medical records (Medifirst ${ }^{\circ}$, Montigny le Bretonneux, France), none of the participants' clinical and laboratory data were missing.

\section{Results}

We analyzed 1210 IVF/ICSI cycles (general population) with a GnRH antagonist - FSH/hMG protocol between 2016 and 2018 in our ART center of the Brest University Hospital. These cycles resulted in 1156 oocyte retrievals (95.5\% per cycle) and 849 embryo transfers $(73.4 \%$ per retrieval). The demographic, clinical and laboratory data on the general population are summarized as a function 
of the presence or absence of a pregnancy and by embryo transfer stage in Table 1. With regard to the demographic variables, the various groups did not differ in term of female age, female and male BMIs, primary infertility, the etiology of the infertility, the AMH level on D3 of the menstrual cycle, and the cycle rank. It is noteworthy that smoking was significantly more frequent among the pregnant women. During ovarian stimulation, the serum progesterone level was significantly higher on the eve of the hCG day and on the day itself among the non-pregnant women. We also noted a difference in the serum LH level as a function of pregnancy, depending on the transfer stage; the LH level was higher among pregnant women than non-pregnant women in the blastocyst transfer group but lower among pregnant women than non-pregnant women in the cleaved embryo transfer group. Among the non-pregnant women, the fertilization rate was significantly lower in the cleaved embryo transfer group $(p<0.02)$. Two hundred and forty-two clinical pregnancies were obtained $(28.5 \%$ per transfer), including 112 after blastocyst transfers (33.3\% per transfer; implantation rate (IR): $27.7 \%$ ) and 130 after cleaved embryo transfers $(25.3 \%$ per transfer; IR: $17.2 \% ; p<0.01)$. We recorded 99 ongoing pregnancies $(29.4 \%$ per transfer) and 108 live births $(32.1 \%$ per transfer; 9 of the births (8.2\%) corresponded to twin pregnancies) after blastocyst transfer, and 112 ongoing pregnancies $(21.8 \%$ per transfer; $p<0.02)$ and 117 live births $(22.8 \%$ per transfer; $p<0.01 ; 5$ of the births $(3.8 \%)$ corresponded to twin pregnancies) after cleaved embryo transfer.

Of the 1210 cycles, 677 (55.9\%) met the "top cycle" criteria. They resulted in 642 oocyte retrievals $(94.8 \%$ per cycle) and 377 embryo transfers (58.7\% per retrieval). The demographic, clinical and laboratory data in the "top cycle" selected population are summarized as a function of the presence or absence of a pregnancy and by embryo transfer stage in Table 2 . With regard to the demographic variables, the groups did not differ significantly other than for the cycle rank (low in the women who became pregnant after blastocyst transfer and high in the women who became pregnant after cleaved embryo transfer). During ovarian stimulation, the serum progesterone level was significantly higher on the eve of the hCG day and on the day itself among the nonpregnant women. We also found a difference in the serum LH level, which was significantly higher among the pregnant women than the non-pregnant women in both the blastocyst transfer and cleaved embryo transfer groups. It is noteworthy that the clinical pregnancy rate in women aged $\geq 35$ and/or with 3 or more cycles was $30.9 \%$ after blastocyst transfer $(n=168)$ and $18 \%$ after cleaved embryo transfer $(n=304)$ (data not shown). One hundred and thirty-five clinical pregnancies were obtained (35.8\% per transfer), including 60 after a blastocyst transfer (35.7\% per transfer; IR: $32.4 \%$ ) and 75 after a cleaved embryo transfer (35.8\% per transfer; IR: 30.9\%; $\mathrm{p}=$ not significant - NS; Fig. 1). We observed 55 ongoing pregnancies (32.7\% per transfer) and 57 live births (33.9\% per transfer; 1 of the births (1.6\%) corresponded to a twin pregnancy) after blastocyst transfer, and 69 ongoing pregnancies $(33.0 \%$ per transfer; $\mathrm{p}=\mathrm{NS})$ and 73 live births $(34.9 \%$ per transfer; $\mathrm{p}=\mathrm{NS} ; 4$ of the births (5.3\%) corresponded to twin pregnancies) after cleaved embryo transfer.

The lower transfer rates per retrieval were due to the significantly higher number of culture failures and freeze-all procedures for the "top cycle" population in both the blastocyst transfer and cleaved embryo transfer groups (Fig. 1). In our study, $2.1 \%$ of the cycles had a progesterone level $\geq 1.5 \mathrm{ng} / \mathrm{ml}$ on the trigger day (range: 1.5 to 2.9). With regard to the 69 planned cases of "freeze all" in the general population, 13 couples did not have any embryos frozen, and the other 56 had a mean of $2.96 \pm 2.03$ embryos frozen. In the "top cycle" selected population, 6 couples in each group (i.e. the blastocyst transfer group and the cleaved embryo transfer group) did not have any frozen embryos, and the others obtained $3.43 \pm 2.14$ (range: $1-10$ ) and $3.44 \pm 2.11$ (range: 1-10) frozen embryos, respectively. In our ART center, the pregnancy rates after frozen embryo transfer have been above $20 \%$ for the last few years, so we expect to obtain good cumulative pregnancy rate (for fresh + frozen transfers). In the general population, the retrieval failure rate (no oocytes) was significantly higher in the blastocyst group transfer group (5.7\%) than in the cleaved embryo transfer group (1.7\%; $p<0.001)$.

The calculated POI, P:E2 and PFI ratios are given in Table 3. The POI differed significantly according to the type of transfer in the general population, and was significantly lower in the selected population than in the general population. The P:E2 ratio did not differ significantly - probably because it was well below the threshold for premature luteinization. All the PFI values were significantly higher $(p<0.001)$ in the selected population than in the general population, and there was a significant difference $(\mathrm{p}<0.001)$ between pregnant and nonpregnant women in the cleaved embryo transfer group.

Figure 2 shows the clinical pregnancy rates by population and type of transfer, relative to the serum progesterone threshold of $0.9 \mathrm{ng} / \mathrm{ml}$ on the hCG day. We noted a significant difference above vs. below this threshold in the general population (after either blastocyst or cleaved embryo transfer) but not in the selected population. Figure 3 details the clinical pregnancy rate by serum progesterone class; it highlights the difference between the general population and the selected population and explains (at least in part) the results presented in Fig. 2. 
Table 1 Demographic, clinical and laboratory data for the general population after blastocyst or cleaved embryo transfer. Analysis between pregnant and not pregnant women

\begin{tabular}{|c|c|c|c|c|c|c|}
\hline Variables & $\begin{array}{l}\text { Blastocyst } \\
\text { Pregnancy }\end{array}$ & $\begin{array}{l}\text { Blastocyst } \\
\text { No pregnancy }\end{array}$ & $p$ & $\begin{array}{l}\text { Cleaved embryo } \\
\text { Pregnancy }\end{array}$ & $\begin{array}{l}\text { Cleaved embryo } \\
\text { No pregnancy }\end{array}$ & p \\
\hline Female age (y.o) & $33.8 \pm 6.8$ & $33.4 \pm 7.8$ & NS & $33.1 \pm 7.4$ & $33.7 \pm 9.2$ & NS \\
\hline Female BMI $\left(\mathrm{kg} / \mathrm{m}^{2}\right)$ & $24.8 \pm 4.5$ & $25.0 \pm 5.0$ & NS & $25.2 \pm 4.7$ & $24.9 \pm 4.2$ & NS \\
\hline Female tobacco \% & $50.0^{c}$ & $32.0^{9}$ & $<0.001$ & $35.0^{d}$ & $24.6^{\mathrm{h}}$ & $<0.05$ \\
\hline Male BMI $\left(\mathrm{kg} / \mathrm{m}^{2}\right)$ & $25.1 \pm 3.3$ & $25.2 \pm 3.8$ & NS & $25.4 \pm 7.3$ & $24.8 \pm 8.7$ & NS \\
\hline Male tobacco \% & 51.8 & $33.0^{c}$ & $<0.001$ & 43.8 & $44.0^{d}$ & NS \\
\hline Primary infertility \% & 65.0 & 60.8 & NS & 59.6 & 62.5 & NS \\
\hline \multicolumn{7}{|l|}{ Indications \% } \\
\hline Tubal disorder & 16.2 & 17.9 & NS & 15.7 & 13.9 & NS \\
\hline Endometriosis & 6.3 & 7.7 & NS & 7.1 & 6.0 & NS \\
\hline Ovulatory dysfunction & 6.8 & 7.0 & NS & 3.5 & 4.6 & NS \\
\hline Low ovarian reserve & 5.6 & 6.0 & NS & 10.7 & 10.7 & NS \\
\hline Unexplained & 14.5 & 9.9 & NS & 11.4 & 8.9 & NS \\
\hline Male factor & 28.7 & 33.6 & NS & 35.7 & 35.0 & NS \\
\hline Mixed & 21.8 & 17.9 & NS & 15.7 & 21.0 & NS \\
\hline $\mathrm{AMH}, \mathrm{ng} / \mathrm{ml}$ & $3.46 \pm 2.41^{\mathrm{a}}$ & $3.05 \pm 2.70^{a}$ & NS & $1.95 \pm 0.66^{b}$ & $2.07 \pm 1.10^{b}$ & NS \\
\hline Retrieval rank $(\mathrm{m} \pm \mathrm{SD})$ & $1.05 \pm 0.9$ & $1.14 \pm 0.9^{e}$ & NS & $1.17 \pm 1.0$ & $1.34 \pm 1.3^{f}$ & NS \\
\hline Number of cycles & 160 & 312 & & 192 & 546 & \\
\hline Total dose of Gnt (IU) & $2222 \pm 819^{a}$ & $2281 \pm 633^{a}$ & NS & $2727 \pm 664^{b}$ & $3127 \pm 674^{b}$ & $<0.001$ \\
\hline FSH use, \% & 57.5 & 58.3 & NS & 65.1 & 63.5 & NS \\
\hline Stimulation duration (d) & $10.06 \pm 1.60$ & $9.82 \pm 1.49^{c}$ & NS & $10.07 \pm 1.79$ & $10.18 \pm 1.76^{d}$ & NS \\
\hline Mature follicle hCG day & $3.4 \pm 2.0$ & $4.1 \pm 2.7^{\mathrm{a}}$ & $<0.01$ & $3.2 \pm 1.8$ & $2.5 \pm 2.1^{b}$ & $<0.001$ \\
\hline Estradiol hCG day-2 & $1161 \pm 530$ & $1269 \pm 528$ & $<0.05$ & $1004 \pm 335$ & $1093 \pm 460$ & $<0.05$ \\
\hline Estradiol hCG day-1 & $1677 \pm 607$ & $1750 \pm 723$ & NS & $1472 \pm 398$ & $1464 \pm 675$ & NS \\
\hline Estradiol hCG day & $1973 \pm 613^{a}$ & $1997 \pm 689^{a}$ & NS & $1667 \pm 531^{b}$ & $1733 \pm 722^{b}$ & NS \\
\hline Progesterone hCG day-2 & $0.73 \pm 0.21$ & $0.75 \pm 0.30$ & NS & $0.65 \pm 0.17$ & $0.79 \pm 0.26$ & $<0.001$ \\
\hline Progesterone hCG day-1 & $0.78 \pm 0.29$ & $0.90 \pm 0.29$ & $<0.001$ & $0.75 \pm 0.27$ & $0.84 \pm 0.32$ & $<0.01$ \\
\hline Progesterone hCG day & $0.84 \pm 0.22$ & $0.99 \pm 0.36^{a}$ & $<0.001$ & $0.83 \pm 0.22$ & $0.91 \pm 0.31^{b}$ & $<0.01$ \\
\hline LH hCG day-2 & $2.17 \pm 1.32$ & $1.43 \pm 1.23$ & $<0.001$ & $1.68 \pm 1.19$ & $1.77 \pm 1.32$ & NS \\
\hline LH hCG day-1 & $1.73 \pm 1.19$ & $1.34 \pm 1.28$ & $<0.01$ & $1.37 \pm 0.76$ & $1.88 \pm 1.65$ & $<0.001$ \\
\hline LH hCG day & $1.80 \pm 1.47$ & $1.49 \pm 1.34^{\mathrm{a}}$ & $<0.05$ & $1.61 \pm 0.77$ & $1.90 \pm 1.27^{b}$ & $<0.01$ \\
\hline Endometrium (mm) & $9.51 \pm 1.49^{\mathrm{e}}$ & $9.62 \pm 1.99$ & NS & $9.98 \pm 2.08^{f}$ & $9.60 \pm 1.86$ & NS \\
\hline Stimulation cancelled & $6(3.7 \%)$ & $12(3.8 \%)$ & NS & $8(4.1 \%)$ & $28(5.1 \%)$ & NS \\
\hline Number oocyte retrievals & 154 & 300 & & 184 & 518 & \\
\hline Retrieved oocytes $(\mathrm{m} \pm \mathrm{SD})$ & $9.10 \pm 3.73^{a}$ & $9.64 \pm 4.09^{a}$ & NS & $6.77 \pm 2.68^{b}$ & $6.43 \pm 3.03^{b}$ & NS \\
\hline Mature oocytes $(\mathrm{m} \pm \mathrm{SD})$ & $7.54 \pm 2.73^{\mathrm{a}}$ & $7.84 \pm 3.41^{\mathrm{a}}$ & NS & $5.07 \pm 2.31^{b}$ & $4.71 \pm 2.47^{b}$ & NS \\
\hline ICSI, \% & $57.1^{a}$ & $57.0^{a}$ & NS & $64.6^{\mathrm{b}}$ & $69.1^{\mathrm{b}}$ & NS \\
\hline $2 \mathrm{PN}(\mathrm{m} \pm \mathrm{SD})$ & $5.69 \pm 2.26^{a}$ & $5.87 \pm 2.77^{a}$ & NS & $3.56 \pm 2.11^{b}$ & $2.96 \pm 1.85^{b}$ & $<0.01$ \\
\hline Fertilization rate, $\%$ & 75.5 & $74.9^{a}$ & NS & 70.2 & $62.5^{b}$ & $<0.02$ \\
\hline Total embryos $(\mathrm{m} \pm \mathrm{SD})$ & $5.75 \pm 2.47^{\mathrm{a}}$ & $6.02 \pm 2.68^{a}$ & NS & $3.54 \pm 1.86^{b}$ & $3.08 \pm 1.75^{b}$ & $<0.02$ \\
\hline Cleavage rate, $\%$ & 77.6 & $76.4^{a}$ & NS & 69.8 & $65.4^{\mathrm{b}}$ & NS \\
\hline Blastocyst $(m \pm S D)$ & $2.71 \pm 1.74$ & $2.62 \pm 1.77$ & NS & - & - & \\
\hline$\%$ Blastocyst/embryo & 47.2 & 43.6 & NS & - & - & \\
\hline
\end{tabular}


Table 1 Demographic, clinical and laboratory data for the general population after blastocyst or cleaved embryo transfer. Analysis between pregnant and not pregnant women (Continued)

\begin{tabular}{lllllll}
\hline Variables & $\begin{array}{l}\text { Blastocyst } \\
\text { Pregnancy }\end{array}$ & $\begin{array}{l}\text { Blastocyst } \\
\text { No pregnancy }\end{array}$ & $\mathbf{p}$ & $\begin{array}{l}\text { Cleaved embryo } \\
\text { Pregnancy }\end{array}$ & $\begin{array}{l}\text { Cleaved embryo } \\
\text { No pregnancy }\end{array}$ \\
\hline Culture failure & $42(27.2 \%)$ & $76(25.3 \%)$ & NS & $54(29.3 \%)$ & $135(26.0 \%)$ & NS \\
Number of transfers & $112^{c}$ & 224 & & 130 & 383 & $1.51 \pm 0.89^{d}$ \\
Embryos transferred $(m \pm S D)$ & $1.33 \pm 0.94^{c}$ & $1.30 \pm 0.92^{c}$ & NS & $1.59 \pm 0.40^{d}$ & NS \\
\hline
\end{tabular}

Legends: IU: international unit; Gnt: gonadotropin; endometrium: endometrial thickness

Statistical analysis: The " $\mathrm{p}$ " column indicates the difference between pregnant and not pregnant women in cases of blastocyst or cleaved embryo transfer Difference between blastocyst and cleaved embryo transfers: ${ }^{\mathrm{a}-\mathrm{b}}: p<0.001{ }^{\mathrm{c}-\mathrm{d}}: p<0.01,{ }^{\mathrm{e}-\mathrm{f}}: p<0.02,{ }^{\mathrm{g}-\mathrm{h}}: p<0.05$

Thus, the highest clinical pregnancy rates in the selected population were observed for the $0.91-1.1 \mathrm{ng} / \mathrm{ml}$ class. The highest clinical pregnancy rates in the general population were observed in the $0.51-0.7$ and $0.71-0.9 \mathrm{ng} / \mathrm{ml}$ classes after blastocyst transfer and in the $0.51-0.7$ class after cleaved embryo transfer.

\section{Discussion}

The results of our retrospective study highlighted a significantly higher clinical pregnancy rate after blastocyst transfer (33.3\%) than after cleaved embryo transfer (25.3\%; $p<0.01)$ in the general IVF/ICSI population; the same was true for the live birth rate (32.1 vs. $22.8 \%$, respectively; $\mathrm{p}<0.01$ ). The same difference was found in Glujovsky et al.'s [9] meta-analysis of 27 randomized studies (covering a total of 4031 women or couples); the OR [95\%CI] was 1.30 [1.14-1.47] for clinical pregnancies and 1.48 [1.2-1.82] for births (in 13 studies) after D5/D6 blastocyst transfer. For D5/D6 blastocyst transfer, Wang et al. [8] found an OR of 1.43 [1.15-1.78] for clinical pregnancies (in seven randomized studies) and an OR of 2.15 [1.57-2.94] for births (in four studies). Wang et al. also found that blastocyst transfer was associated with a lower miscarriage rate (OR [95\%CI]: 0.51 [0.3-0.87]), relative to cleaved embryo transfer; this was not the case in our study (with values of $11.6 \%$ vs. $13.8 \%$, respectively, in the general population) or in the meta-analysis by Glujovsky et al. (OR [95\%CI]: 1.15 [0.88-1.50]) [9]. In our study, we transferred blastocysts on D5 only; this yields significantly more pregnancies than on D6, as shown by Bourdon et al.'s [18] meta-analysis (OR [95\%CI]: 2.38 [1.74-3.24] for clinical pregnancies and 1.74 [1.37-2.20] for live births). Other researchers have not found any difference in pregnancy rates per transfer between blastocysts and cleaved embryos: with a serum progesterone level $>1.5 \mathrm{ng} / \mathrm{ml}$ on the trigger day, the rates were respectively 39.6 and $40.1 \%$ in Levi-Setti et al.'s study [19] and 35\% vs. 39\% in Demirel et al.'s study [20]. In our selected "top cycle" population, we did not observe any difference in the clinical pregnancy and live birth rate when comparing the blastocyst transfer and cleaved embryo transfer groups. Likewise, the miscarriage rates were similar: 8.3 vs. $8.0 \%$ in the blastocyst and cleaved embryo transfer groups, respectively. Any difference in embryo culture failure rates in the general and selected IVF/ICSI populations was reported in our study, whereas Glujovsky et al. [9] found a greater risk of no embryo transfer for D5 blastocyst versus D3 embryo.

In our study, the main predictive factor for pregnancy (whether after blastocyst transfer or cleaved embryo transfer) was the serum progesterone level on the eve of the trigger day and on the day itself; the levels were significantly higher among women who did not become pregnant in both the general and selected populations $(p<0.01$ to $<0.001)$. Follicular phase progesterone facilitates the estrogens' action on the pituitary gland, thus enabling the ovulatory peak of LH and FSH. It also has an essential role in decidualization of the endometrium and the opening of the implantation window via the structures or molecules that it controls (the pinopodes, insulin growth factor binding protein 1 and glycodelin levels, etc.) [10]. Hence, in a study of GnRH antagonist FSH protocols, Van Vaerenbergh [21] reported differences in endometrial gene transcription between serum progesterone classes $(\leq 0.9,1-1.5$, and $>1.5 \mathrm{ng} / \mathrm{ml})$. Two pregnancies were found in the first class (out of 3 women), with two in the second (out of 6) and none in the third (out of 5). The largest number of gene transcription differences were observed when comparing the third group with the first group $(n=1388)$ and the second group $(n=819)$. The changes involved the serine protease PAPP-A, the IL-17 receptor, thrombospondin, and dickkopf homolog 3 (Xenopus laevis). Labarta et al. [22] found that a serum progesterone level $>1.5 \mathrm{ng} / \mathrm{ml}$ was associated with differences in the expression of proteins involved in cell adhesion, immunity, and growth. During the proliferative phase, progesterone levels are usually $<0.5 \mathrm{ng} / \mathrm{ml}$, with a luteinization induction threshold of between 1 and $10 \mathrm{ng} / \mathrm{ml}$. Filicori et al. [23] showed that the elevation in progesterone depended on the granulosa cells and (as also reported by other researchers [24-26]) was associated with the number of oocytes retrieved, the dose of $\mathrm{FSH}$, and the serum 
Table 2 Demographic, clinical and laboratory data for the "top cycle" selected population after blastocyst transfers or cleaved embryo transfer. Analysis between pregnant and not pregnant women

\begin{tabular}{|c|c|c|c|c|c|c|}
\hline Variables & $\begin{array}{l}\text { Blastocyst } \\
\text { Pregnancy }\end{array}$ & $\begin{array}{l}\text { Blastocyst } \\
\text { No pregnancy }\end{array}$ & $p$ & $\begin{array}{l}\text { Cleaved embryo } \\
\text { Pregnancy }\end{array}$ & $\begin{array}{l}\text { Cleaved embryo } \\
\text { No pregnancy }\end{array}$ & p \\
\hline Female age (y.o) & $30.7 \pm 2.4$ & $31.0 \pm 2.8$ & NS & $30.4 \pm 2.5$ & $30.3 \pm 2.3$ & NS \\
\hline Female BMI $\left(\mathrm{kg} / \mathrm{m}^{2}\right)$ & $25.2 \pm 4.5$ & $24.7 \pm 2.1$ & NS & $25.7 \pm 4.9$ & $24.8 \pm 4.1$ & NS \\
\hline Female smoking, \% & 26.7 & $19.5^{\mathrm{e}}$ & NS & 31.2 & $29.9^{f}$ & NS \\
\hline Male BMI $\left(\mathrm{kg} / \mathrm{m}^{2}\right)$ & $25.1 \pm 3.3$ & $25.3 \pm 4.3$ & NS & $25.3 \pm 4.0$ & $25.2 \pm 4.2$ & NS \\
\hline Male smoking, $\%$ & 34.2 & $28.3^{9}$ & NS & 38.7 & $38.0^{h}$ & NS \\
\hline Primary infertility, \% & $40.0^{c}$ & $43.8^{a}$ & NS & $61.0^{d}$ & $66.8^{b}$ & NS \\
\hline \multicolumn{7}{|l|}{ Indications \% } \\
\hline Tubal disorder & 16.1 & 15.0 & NS & 15.2 & 13.7 & NS \\
\hline Endometriosis & 6.6 & 8.2 & NS & 7.6 & 6.8 & NS \\
\hline Ovulatory dysfunction & 8.5 & 11.8 & NS & 3.8 & 4.8 & NS \\
\hline Low ovarian reserve & 6.6 & 5.1 & NS & 9.1 & 8.5 & NS \\
\hline Unexplained & 11.4 & 10.8 & NS & 10.6 & 9.7 & NS \\
\hline Male factor & 30.4 & 30.4 & NS & 37.4 & 38.4 & NS \\
\hline Mixed & 20.4 & 18.8 & NS & 16.0 & 17.8 & NS \\
\hline $\mathrm{AMH} \mathrm{ng} / \mathrm{ml}$ & $3.70 \pm 2.19$ & $4.10 \pm 3.60$ & NS & $3.41 \pm 1.99$ & $3.70 \pm 3.39$ & NS \\
\hline Retrieval rank $(\mathrm{m} \pm \mathrm{SD})$ & $0.53 \pm 0.50^{g}$ & $0.65 \pm 0.47^{\mathrm{e}}$ & $<0.05$ & $0.67 \pm 0.46^{h}$ & $0.54 \pm 0.50^{f}$ & $<0.02$ \\
\hline Number of cycles & 105 & 194 & & 131 & 247 & \\
\hline Total dose Gnt (IU) & $2125 \pm 721$ & $1913 \pm 670$ & $<0.02$ & $2203 \pm 853$ & $1965 \pm 813$ & $<0.01$ \\
\hline FSH use, \% & $34.2^{\mathrm{a}}$ & $39.1^{\mathrm{a}}$ & NS & $64.8^{\mathrm{b}}$ & $61.9^{b}$ & NS \\
\hline Stimulation duration (d) & $10.0 \pm 1.58$ & $10.22 \pm 2.96$ & NS & $10.1 \pm 1.5$ & $10.1 \pm 2.7$ & NS \\
\hline Mature follicle hCG day & $2.52 \pm 2.25$ & $3.11 \pm 2.98^{c}$ & NS & $2.82 \pm 2.72$ & $2.22 \pm 2.00^{d}$ & $<0.05$ \\
\hline Estradiol hCG day-2 & $1155 \pm 586$ & $1264 \pm 513$ & NS & $1142 \pm 584$ & $1235 \pm 513$ & NS \\
\hline Estradiol hCG day-1 & $1624 \pm 630$ & $1706 \pm 593$ & NS & $1601 \pm 584$ & $1608 \pm 681$ & NS \\
\hline Estradiol hCG day & $1899 \pm 573$ & $2039 \pm 628$ & NS & $1832 \pm 583$ & $2012 \pm 665$ & $<0.01$ \\
\hline Progesterone hCG day-2 & $0.75 \pm 0.21$ & $0.76 \pm 0.29$ & NS & $0.76 \pm 0.23$ & $0.75 \pm 0.28$ & NS \\
\hline Progesterone hCG day-1 & $0.78 \pm 0.26$ & $0.89 \pm 0.27$ & $<0.001$ & $0.78 \pm 0.28$ & $0.87 \pm 0.28$ & $<0.01$ \\
\hline Progesterone hCG day & $0.86 \pm 0.21$ & $0.99 \pm 0.39$ & $<0.001$ & $0.86 \pm 0.21$ & $1.00 \pm 0.39$ & $<0.001$ \\
\hline LH hCG day-2 & $2.73 \pm 1.86$ & $1.61 \pm 1.39$ & $<0.001$ & $2.66 \pm 1.72$ & $1.55 \pm 1.31$ & $<0.001$ \\
\hline LH hCG day-1 & $1.42 \pm 0.81$ & $1.34 \pm 1.16$ & NS & $1.51 \pm 0.83$ & $1.41 \pm 1.27$ & NS \\
\hline LH hCG day & $2.15 \pm 1.30$ & $1.58 \pm 1.47$ & $<0.001$ & $2.25 \pm 1.31$ & $1.68 \pm 1.43$ & $<0.001$ \\
\hline Endometrium (mm) & $9.63 \pm 1.47$ & $9.54 \pm 1.78$ & NS & $9.66 \pm 1.51$ & $9.53 \pm 1.75$ & NS \\
\hline Stimulation cancelled & $5(4.7 \%)$ & $11(5.6 \%)$ & NS & $6(4.5 \%)$ & $13(5.2 \%)$ & NS \\
\hline Number oocyte retrievals & 100 & 183 & & 125 & 234 & \\
\hline Retrieved oocytes $(\mathrm{m} \pm \mathrm{SD})$ & $8.73 \pm 3.25$ & $9.89 \pm 3.74$ & $<0.01$ & $8.16 \pm 3.24$ & $9.26 \pm 3.81$ & $<0.01$ \\
\hline Mature oocytes $(m \pm S D)$ & $7.38 \pm 2.64$ & $7.96 \pm 3.06$ & NS & $6.85 \pm 2.71$ & $7.35 \pm 3.19$ & NS \\
\hline ICSI, \% & $34.6^{\mathrm{a}}$ & $32.9^{a}$ & NS & $57.3^{b}$ & $53.7^{\mathrm{b}}$ & NS \\
\hline $2 \mathrm{PN}(\mathrm{m} \pm \mathrm{SD})$ & $5.40 \pm 2.40$ & $6.06 \pm 2.68^{c}$ & $<0.05$ & $4.90 \pm 2.44$ & $5.36 \pm 2.87^{d}$ & NS \\
\hline Fertilization rate, \% & 74.3 & 76.1 & NS & 72.5 & 72.9 & NS \\
\hline Total embryos $(\mathrm{m} \pm \mathrm{SD})$ & $5.18 \pm 2.35$ & $6.15 \pm 2.55^{c}$ & $<0.01$ & $4.94 \pm 2.45$ & $5.48 \pm 2.71^{d}$ & NS \\
\hline Cleavage rate, $\%$ & 75.4 & 77.3 & NS & 73.1 & 74.5 & NS \\
\hline Blastocyst $(m \pm S D)$ & $2.93 \pm 1.77$ & $3.25 \pm 1.91$ & NS & - & - & \\
\hline$\%$ Blastocyst/embryo & 53.5 & 52.7 & NS & - & - & \\
\hline
\end{tabular}


Table 2 Demographic, clinical and laboratory data for the "top cycle" selected population after blastocyst transfers or cleaved embryo transfer. Analysis between pregnant and not pregnant women (Continued)

\begin{tabular}{lllllll}
\hline Variables & $\begin{array}{l}\text { Blastocyst } \\
\text { Pregnancy }\end{array}$ & $\begin{array}{l}\text { Blastocyst } \\
\text { No pregnancy }\end{array}$ & $\mathbf{p}$ & Cleaved embryo & $\begin{array}{l}\text { Cleaved embryo } \\
\text { Pregnancy }\end{array}$ & $\begin{array}{l}\mathbf{p} \\
\text { No pregnancy }\end{array}$ \\
\hline Culture failure & $40(40.0 \%)$ & $75(40.9 \%)$ & NS & $50(40.0 \%)$ & $100(42.7 \%)$ & NS \\
Number of transfers & 60 & 108 & & 75 & 134 & $1.14 \pm 0.35$ \\
Embryo transferred (m \pm SD) & $1.15 \pm 0.34$ & $1.13 \pm 0.33$ & NS & $1.17 \pm 0.37$ & NS \\
\hline
\end{tabular}

Legends: IU: international unit; Gnt: gonadotropin; endometrium: endometrial thickness

Statistical analysis: The " $\mathrm{p}$ " column indicates the difference between pregnant and not pregnant women in cases of blastocyst or cleaved embryo transfer Difference between blastocyst and cleaved embryo transfers: ${ }^{\mathrm{a}-\mathrm{b}}: p<0.001,{ }^{\mathrm{c}-\mathrm{d}}: p<0.01,{ }^{\mathrm{e}-\mathrm{f}}: p<0.02,{ }^{\mathrm{g}-\mathrm{h}}: p<0.05$

estradiol level. This premature elevation led some researchers $[27,28]$ to recommend an earlier trigger. The elevated serum progesterone level on the trigger day affects the endometrium but not embryo quality, as shown in Huang et al.'s study [29] and by the results of frozen embryo or donor embryo transfers [14, 24, 30]. Furthermore, the very high serum estradiol level accelerates endometrial maturation (with no pregnancies if the advance exceeds 3 days [31]) and leads to luteal-phase $\mathrm{LH}$ deficiency, luteolysis, myometrial hypercontractility, and differences in gene transcription. Saadat et al. [32] found that the mean $\pm \mathrm{SD}$ acceleration in endometrial maturation was the same for antagonist protocols $(5.8 \pm 0.4$ days) and agonist protocols ( $5.9 \pm 0.7$ days $)$ and persisted up until 7 days after the trigger.

Elevated progesterone levels before the ovulation trigger are responsible for a decrease in pregnancy rates. The research question addressed in the literature

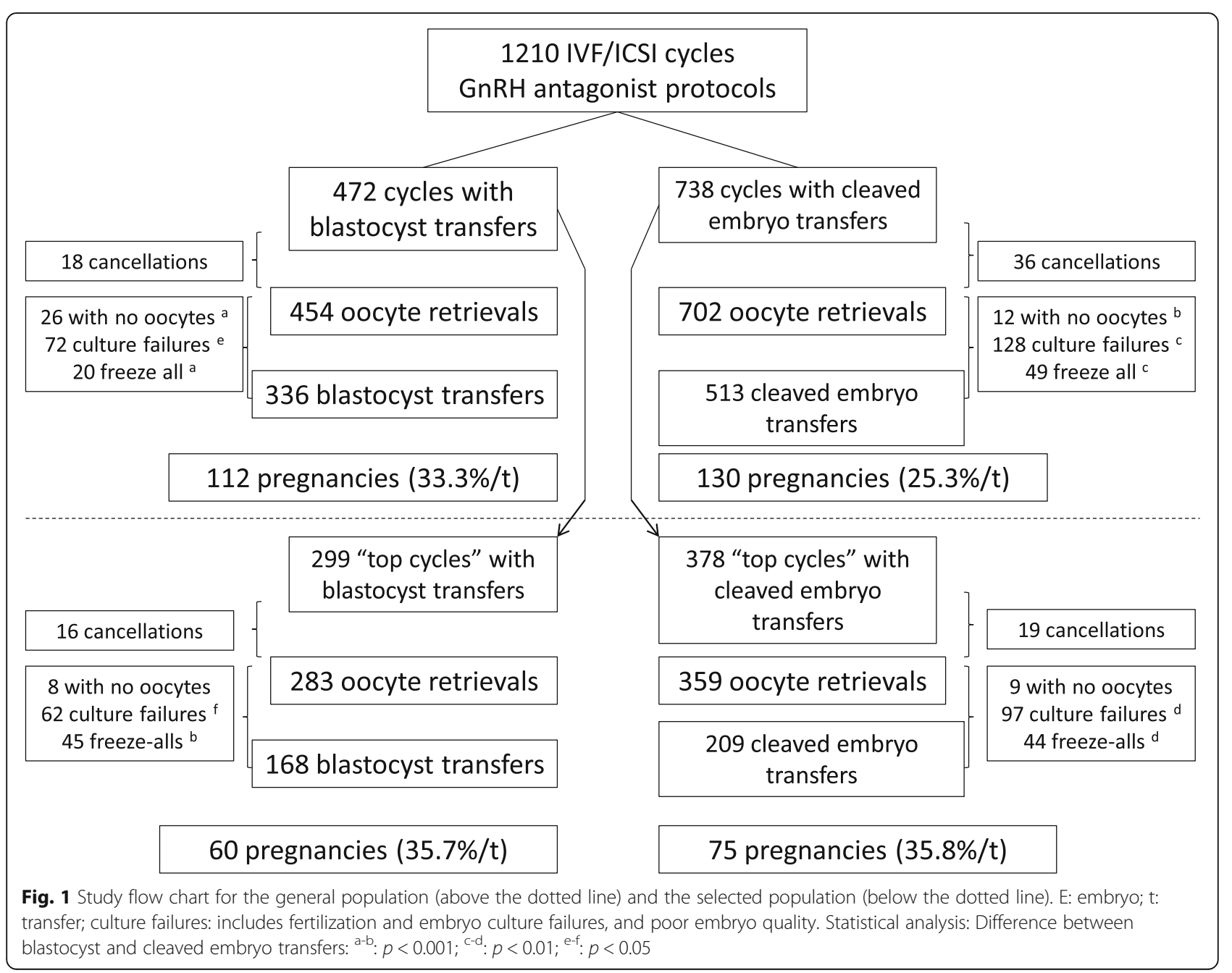


Table 3 Results for the various index/ratios involving the serum progesterone level on the hCG trigger day. Analysis between pregnant and not pregnant women, blastocyst or cleaved embryo transfers, and general or selected populations

\begin{tabular}{|c|c|c|c|c|c|c|}
\hline Variables & $\begin{array}{l}\text { Blastocyst } \\
\text { Pregnancy }\end{array}$ & $\begin{array}{l}\text { Blastocyst } \\
\text { No pregnancy }\end{array}$ & $p$ & $\begin{array}{l}\text { Cleaved embryo } \\
\text { Pregnancy }\end{array}$ & $\begin{array}{l}\text { Cleaved embryo } \\
\text { No pregnancy }\end{array}$ & $p$ \\
\hline \multicolumn{7}{|l|}{ General population } \\
\hline cycles: n & 160 & 312 & & 192 & 546 & \\
\hline POI (ng/ml/oocyte) & $0.092 \pm 0.058$ & $0.102 \pm 0.068$ & NS & $0.122 \pm 0.072^{c}$ & $0.141 \pm 0.082^{a}$ & $<0.01$ \\
\hline P:E2 (pg/ml/pg/ml) & $0.42 \pm 0.35$ & $0.49 \pm 0.32$ & $<0.05$ & $0.49 \pm 0.31$ & $0.52 \pm 0.32$ & NS \\
\hline PFI (nmole/l/follicle) & $0.78 \pm 0.34^{\mathrm{a}}$ & $0.76 \pm 0.42^{\mathrm{a}}$ & NS & $0.82 \pm 0.38^{\mathrm{a}}$ & $1.15 \pm 0.46^{\mathrm{a}}$ & $<0.001$ \\
\hline \multicolumn{7}{|l|}{ Selected population } \\
\hline cycles: n & 105 & 194 & & 131 & 247 & \\
\hline POI (ng/ml/oocyte) & $0.098 \pm 0.064$ & $0.100 \pm 0.084$ & NS & $0.105 \pm 0.065^{d}$ & $0.107 \pm 0.072^{b}$ & NS \\
\hline P:E2 (pg/ml/pg/ml) & $0.45 \pm 0.36$ & $0.48 \pm 0.32$ & NS & $0.46 \pm 0.36$ & $0.49 \pm 0.38$ & NS \\
\hline PFI (nmole/l/follicle) & $1.08 \pm 0.29^{b}$ & $1.01 \pm 0.41^{\mathrm{b}}$ & NS & $0.96 \pm 0.24^{b}$ & $1.43 \pm 0.62^{b}$ & $<0.001$ \\
\hline
\end{tabular}

Legends: $P O I$ progesterone to oocyte index, P:E2 progesterone to estradiol ratio, PFI progesterone to follicle index, NS not significant

Statistical analysis: The " $\mathrm{p}$ " column indicates the difference between pregnant and not pregnant women in cases of blastocyst or cleaved embryo transfer

Difference between general and selected population ("top cycles") for each index or ratio after blastocyst or cleaved embryo transfers: ${ }^{\text {a-b }} p<0.001$, ${ }^{c-d} p<0.05$

concerns the serum progesterone threshold above which this effect appears. According to Bosch et al. [33], the threshold is $1.5 \mathrm{ng} / \mathrm{ml}$, whereas $\mathrm{Xu}$ et al. [26] quoted values of 1.5 to $2.75 \mathrm{ng} / \mathrm{ml}$, depending on the follicular response. In fact, Xu et al.'s study of 10,000 cycles [26] found a fall in the rates of pregnancy above $2.75 \mathrm{ng} / \mathrm{ml}$ in strong responders (> 20 oocytes), above $1.75 \mathrm{ng} / \mathrm{ml}$ in normal responders, and above $1.5 \mathrm{ng} / \mathrm{ml}$ in nonresponders. In contrast, the pregnancy rates for frozen embryo transfers increased with the serum progesterone level. In our study, 77 couples in the selected population had frozen embryos after freeze-all (mean number of embryos frozen: $3.43 \pm 2.14$ ), which prompts us to expect even higher cumulative pregnancy and birth rates. Corti et al. [34] reported a difference in the clinical pregnancy rate above vs. below a serum progesterone threshold of $1.5 \mathrm{ng} / \mathrm{ml}$. (50\% vs $33.3 \%$, respectively; OR [95\%CI]: 2 [1.07-3.75]). Other researchers have found a lower serum progesterone threshold. Venetis et al.'s study of 60,000 cycles [14] found an OR for birth of 0.39 when the serum progesterone level on the trigger day was between $0.4-0.6 \mathrm{ng} / \mathrm{ml}$, with 0.79 between 0.8 and $1.1 \mathrm{ng} /$

CPR per transfer $(\%)$

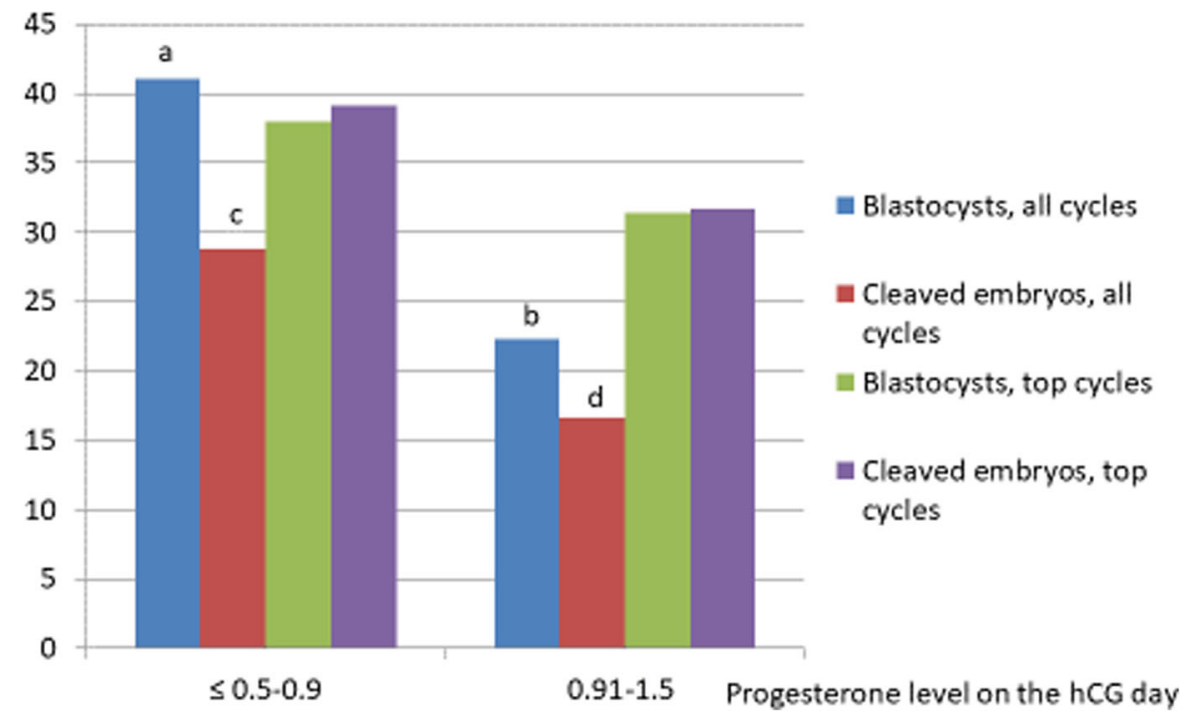

Fig. 2 Clinical pregnancy rates above and below the progesterone threshold ( $\leq 0.9$ and $>0.9 \mathrm{ng} / \mathrm{ml})$, after blastocyst or cleaved embryo transfers in general (all cycles) and selected (top cycles) populations. CPR: clinical pregnancy rate. Statistical analysis: ${ }^{a-b}: p<0.02{ }^{c-d}: p<0.05$ 
A

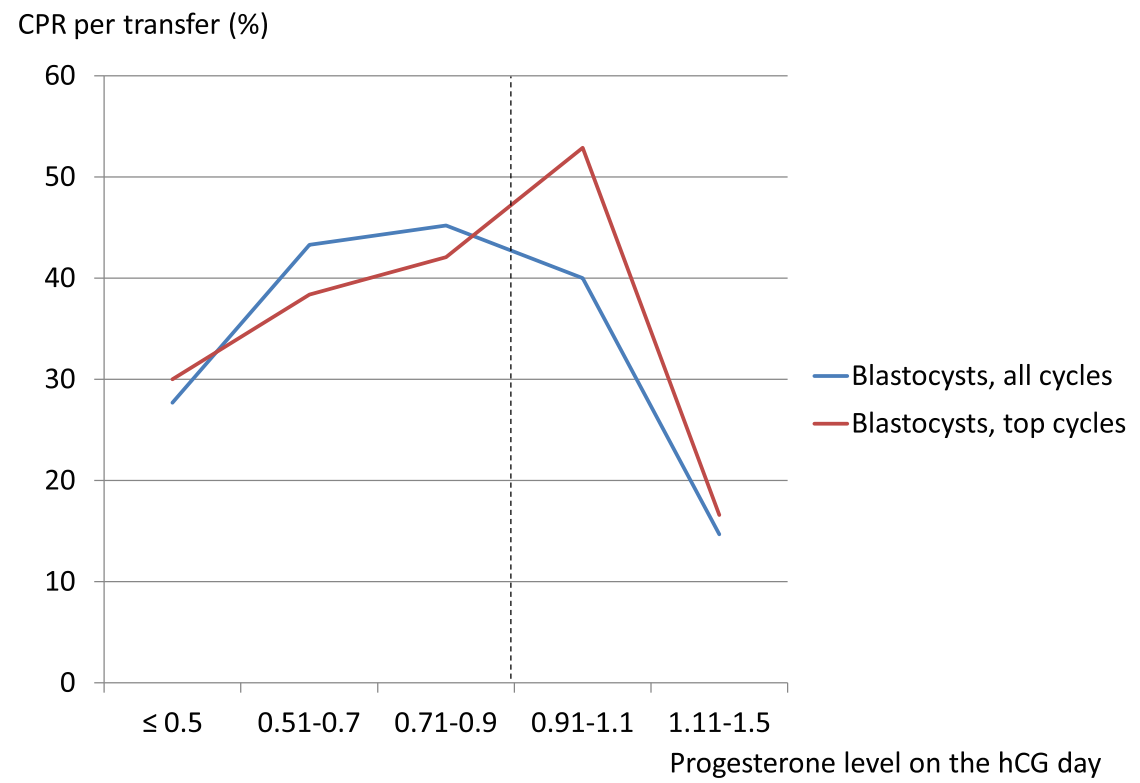

B

CPR per transfer (\%)

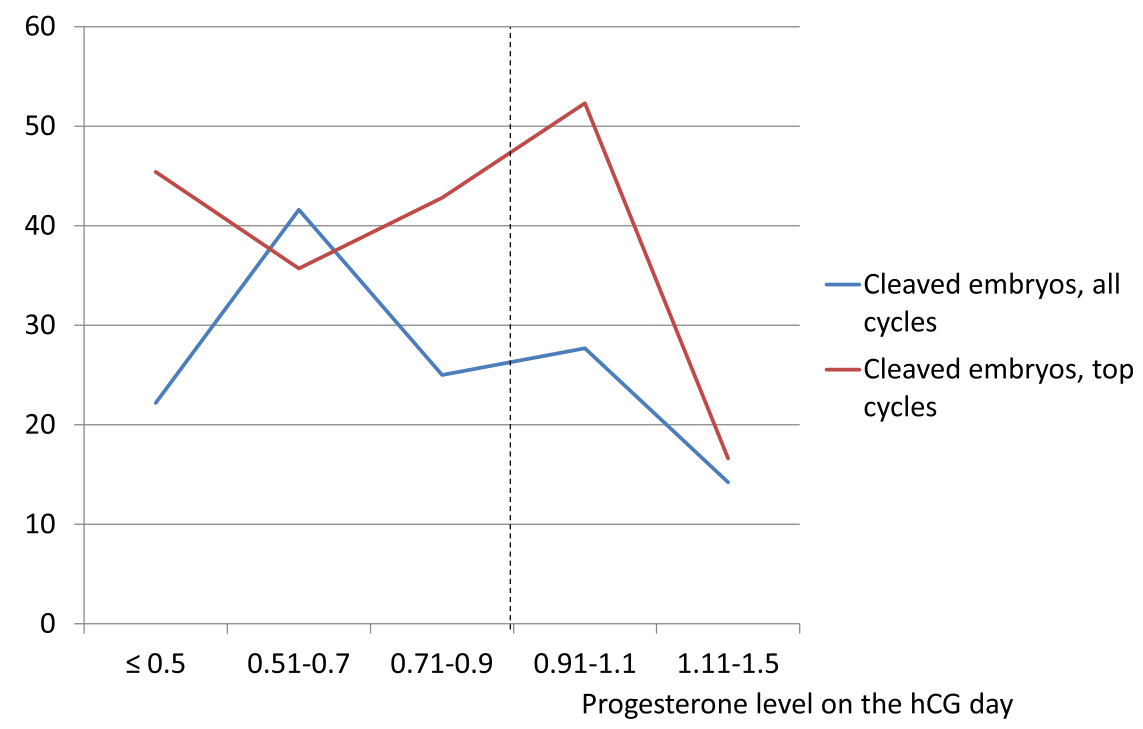

Legends: CPR: clinical pregnancy rate

Fig. 3 Clinical pregnancy rates as a function of the progesterone range $(\mathrm{ng} / \mathrm{ml})$ after blastocyst transfers $(\mathbf{a})$ and cleaved embryo transfers (b), in general (all cycles) and selected (top cycles) populations. CPR: clinical pregnancy rate

$\mathrm{ml}, 0.67$ between 1.2 and $1.4 \mathrm{ng} / \mathrm{ml}, 0.64$ between 1.5 and $1.75 \mathrm{ng} / \mathrm{ml}$, and 0.68 between 1.9 and $3 \mathrm{ng} / \mathrm{ml}$. Venetis et al. did not observe an impact of a serum progesterone level $\geq 1.5 \mathrm{ng} / \mathrm{ml}$ in poor responders $(<6$ oocytes, $n=796$ cycles) or strong responders ( $>18$ oocytes, $n=$ 730). In 2015, the same research group found a threshold of $0.9 \mathrm{ng} / \mathrm{ml}$ for 3296 cycles [35]. Griesinger et al. [36] found that the prevalence of an elevated serum 
progesterone level varied with the follicular response: $4.5 \%$ for poor responders ( $\leq 5$ oocytes) vs. $19 \%$ for strong responders ( $>18$ oocytes). The pregnancy rate was also low (OR: 0.55 [0.37-0.81]), especially in poor responders. Fanchin et al. [37] came to the same conclusion in poor responders for a serum progesterone threshold at $0.9 \mathrm{ng} / \mathrm{ml}$ but this level did not have an impact among normal responders. Requena et al. [38] found the same pregnancy rates in strong responders (> 20 oocytes and $3000 \mathrm{pg} / \mathrm{ml}$ ) above and below a serum progesterone level of $1.5 \mathrm{ng} / \mathrm{ml}$. In our study, the serum estradiol level on the trigger day and the number of oocytes retrieved testified to a normal response to ovarian stimulation. Santos-Ribeiro et al. [39] found the best pregnancy rate $(29.7 \%)$ when the serum progesterone level was between 0.76 and $1 \mathrm{ng} / \mathrm{ml}$, after adjustment for female age, the number of oocytes retrieved, the serum estradiol level, the FSH dose, the number of embryos transferred, and the embryo stage. Wang et al. [40] studied the pregnancy rates after transfers of fresh embryos $(n=1455)$ or frozen embryos $(n=1455)$. They observed than when the serum progesterone level $\leq 1 \mathrm{ng} / \mathrm{ml}$, the pregnancy rates for fresh and frozen embryo transfers were respectively of 56.4 and $54.6 \%$ in women aged $\leq 35$ and 45.1 and $48.9 \%$ in woman over 35 . When the serum progesterone level exceeded $1 \mathrm{ng} / \mathrm{ml}$, the rate after fresh embryo transfer was lower $(46.1 \%$ for age $\leq 35$; OR: 1.38 [1.11-1.71], and $35.2 \%$ for age $>35$; OR: 1.73 [1.342.24]); these values are similar to those found in the present study for the general population vs. the "top cycle" population. Papanikolaou et al. [41] studied the clinical pregnancy rate in $\mathrm{GnRH}$ antagonist-rFSH protocols as a function of the serum progesterone level on the trigger day. In case of transfer of embryos on D3, the clinical pregnancy rate was $37.5 \%$ when the progesterone level was $<0.73 \mathrm{ng} / \mathrm{ml}, 34 \%$ for the range $0.74-0.90$, $30.6 \%$ for the range $0.91-1.2,25.9 \%$ for the range $1.21-$ 1.53 , and $15.7 \%$ when the level was $>1.53 \mathrm{ng} / \mathrm{ml}(p=$ 0.008). Following blastocyst transfer on D5, there was no significant difference in the pregnancy rates as a function of the serum progesterone level $(<0.67$ : 42.9\%; $0.68-0.99$ : $39.5 \%$; $1-1.15$ : $29.3 \%$; $1.16-1.48: 40 \%$, and $>$ 1.48: $41.5 \%)$. The authors concluded that the transfer of a good-quality blastocyst compensates for the high progesterone level. In 2012, the same research group [42] did not find a difference for a serum progesterone level above or below a threshold of $1.5 \mathrm{ng} / \mathrm{ml}$ in either $\mathrm{GnRH}$ antagonist or GnRH agonist protocols. In a study by Vanni et al. [43], the serum progesterone threshold for obtaining good-quality blastocysts was $1.49 \mathrm{ng} / \mathrm{ml}$, and the yield was better below $1 \mathrm{ng} / \mathrm{ml}$. Shapiro et al. [44] reported a lower pregnancy rate after fresh blastocyst transfer on D6 (relative to D5); this was probably due to transfer outside the implantation window, which is advanced by the ovarian stimulation (the pregnancy rate was the same for frozen embryo transfers). Healy et al. [45] compared D5 and D6 transfers and observed an influence of the serum progesterone level above $0.8 \mathrm{ng} / \mathrm{ml}$. On D6, the relative decrease in the pregnancy rate was $8 \%$ when the serum progesterone level was normal and $17 \%$ when it was $>1.5 \mathrm{ng} / \mathrm{ml}$. On D5, the best pregnancy rate was obtained when the serum progesterone level was $<1 \mathrm{ng} / \mathrm{ml}$, with an OR [95\%CI] of $0.75[0.67-0.88]$ $(p<0.001)$ when considering the serum progesterone level as a continuous variable. According to Huang et al. [29], the best pregnancy rates were observed after embryo transfers on D3 or D5 when the serum progesterone level was between 0.5 and $0.74 \mathrm{ng} / \mathrm{ml}$. Overall, $50.4 \%$ of the women became pregnant when the serum progesterone level was $<1 \mathrm{ng} / \mathrm{ml}$, with $45.5 \%$ when it was between 1 and $1.49 \mathrm{ng} / \mathrm{ml}$ and $36.2 \%$ when it was $\geq 1.5 \mathrm{ng} /$ $\mathrm{ml}(p<0.01)$. In our study (with a threshold of $0.9 \mathrm{ng} /$ $\mathrm{ml}$ ), there was a significant difference in the clinical pregnancy rate between the blastocyst transfer and cleaved embryo transfer groups in the general population but not in the selected "top cycle" population (Fig. 2). Unlike Hill et al. [46] who have showed that an elevated serum $P$ level on the day of hCG administration was negatively associated with live birth, even in good prognosis embryo transfers, but in accordance with Papanikolaou et al. [41], it appears in our study that the selection of "top cycles" reduced the impact of an elevated serum progesterone level on the trigger day. This influence can be seen in our Fig. 3, where the clinical pregnancy rates were high in the selected population up to a serum progesterone level of $1.1 \mathrm{ng} / \mathrm{ml}$ for both blastocyst transfer and cleaved embryo transfer.

Lastly, the serum progesterone level was independent of the type of gonadotropin and the duration of administration $[38,47,48]$, as shown by the absence of a difference for these parameters in our study. In a report published in 2014, Lee et al. [49] showed that elevation of the progesterone level for 2 or more days was associated with a lower pregnancy rate $(20.7 \%$, vs. 39.4 for women with a normal level; $p<0.001)$. This might explain our results in the general population and the selected population, where the serum progesterone levels during the last two days of the stimulation were significantly higher in non-pregnant women (regardless of the embryo transfer stage). Nevertheless, Santos-Ribeiro et al. [50] did not find a lower birth rate when the serum progesterone level was above $1 \mathrm{ng} /$ $\mathrm{ml}$ (even after more than a day with elevated levels before the trigger), whereas the rate fell when the serum progesterone level was $>1.5 \mathrm{ng} / \mathrm{ml}$ ( $30.3 \%$ in the absence of an elevated serum progesterone level, $20.4 \%$ for one day of elevation, and $20.5 \%$ for more than one day). However, a progesterone level $>1.5 \mathrm{ng} / \mathrm{ml}$ was very infrequent $(1.9 \%)$ in Santos-Ribeiro et al.'s study. 
We studied various ratios involving the serum progesterone level on the trigger day (Table 3): POI, P:E2, and PFI. The PFI was considerably higher in the general population than in the selected population, and considerably higher $(p<0.001)$ in the women receiving a cleaved embryo transfer (regardless of whether or not they became pregnant). Shufaro et al. [17] estimated that the PFI was more representative of follicular progesterone secretion and the cycle outcome than the mere number of oocytes collected. For 8649 cycles followed by cleaved embryo transfer, the researchers found that the mean PFI was $0.32 \pm 0.25 \mathrm{nM}$, and that the chance of pregnancy was four times lower if the PFI was high ( $>93$ rd percentile, i.e. a serum progesterone level $>4.2$ $\mathrm{nM}$ and a PFI $>0.6$ ). The pre-ovulatory serum progesterone level was $2.22 \pm 1.33 \mathrm{nM}$ in Shufaro et al.'s study. The authors recommended using the PFI rather than the progesterone level on the trigger day to decide whether to continue a cycle (i.e. with a low PFI) or to abandon it (i.e. with a high PFI and, in some cases, a high serum progesterone level). In our study, the PFI was always above 0.6 (probably because of a low serum progesterone level) and was significantly higher in the selected population and in non-pregnant women after cleaved embryo transfer; these findings are in line with Shufaro et al.'s findings [17], which did not apply to cases of blastocyst transfer. The POI even differed significantly when comparing pregnant and non-pregnant women after a cleaved embryo transfer in the general population $(p<0.01)$. Furthermore, and in contrast to the PFI, the POI after cleaved embryo transfer was significantly lower in the selected populations than in the general populations - regardless of whether pregnancy was achieved. Grin et al. [15] showed that the POI was inversely correlated with the clinical pregnancy rate (adjusted OR 95\%CI: 0.063 [0.016-0.249]; $p<0.001$ ) and the birth rate $(0.036$ [0.007-0.199]; $\mathrm{p}<0.001)$, and that the 90th percentile of this ratio was $0.36 \mathrm{ng} / \mathrm{ml} /$ oocyte (clinical pregnancy rate: $8 \%$; birth rate: $5.9 \%$ ). It is noteworthy that the POI was always well below $0.36 \mathrm{ng} / \mathrm{ml} /$ oocyte in our study. For the P:E2 ratio (indicating premature luteinization when $>1$ [16] or $\geq 1.2$ [51]), we only found a significant difference for blastocyst transfers in the general population. In Lai et al.'s study [51] of GnRH agonist protocols, a P:E2 ratio $<1.2$ (mean: $0.6 \pm 0.3 \mathrm{ng} / \mathrm{ml}$ ) had no impact on the ongoing pregnancy rate $(29.3 \%$, vs. $34.5 \%$ for P:E2 > 1.2). The sensitivity was $75 \%$, the specificity was $32 \%$, the positive predictive value was $37 \%$, the negative predictive value was $71 \%$, and the area under the ROC curve [95\%CI] was 0.534 [0.456-0.613], corresponding to poor predictive value for the P:E2 ratio in $\mathrm{GnRH}$ agonist protocols. In a study of women who responded strongly to a GnRH agonist protocol, Lee et al. [52] found that the highest pregnancy rates were achieved with a serum progesterone level $\leq 0.9 \mathrm{ng} / \mathrm{ml}$ or between 0.9 and $1.4 \mathrm{ng} / \mathrm{ml}$, with mean \pm SD P:E2 ratios of $0.18 \pm 0.01$ and $0.27 \pm 0.01$, respectively. It is probable that the premature luteinization threshold in Lee et al.'s study (P:E2 >1) was low because the hyperstimulation had already contributed to an acceleration in endometrial maturation [53]. In a study of women with a serum progesterone level $\geq 1.5 \mathrm{ng} / \mathrm{ml}$ during $\mathrm{GnRH}$ antagonist protocols, Golbasi et al. [54] showed that the P:E2 ratio did not have predictive power (mean value: $0.73 \pm 0.54$ for births vs. $1.05 \pm 1.38$ in the absence of births; $p=$ 0.158). In GnRH agonist protocols, effective blockade of LH elevation (in 95-98\% of the women) meant that the elevated serum progesterone level before the trigger must have been caused by another factor. Hence, in our study (where the P:E2 ratio was always below 0.6), the LH level was higher (in 75\% of cases) among women with a low serum progesterone level on the trigger day. This finding was also described by Huang et al. [29]: the mean \pm SD serum LH level on the trigger day after cleaved embryo transfer on D3 was $2.0 \pm 1.3 \mathrm{IU} / \mathrm{l}$ when the serum progesterone level was $<1 \mathrm{ng} / \mathrm{ml}$ and $1.7 \pm$ $1.0 \mathrm{IU} / \mathrm{l}$ when it was $\geq 1.5 \mathrm{ng} / \mathrm{ml}(p<0.01)$. The use of hMG (with hCG activity) for ovarian stimulation might explain these results [55]; however, we did not find a significant difference between the pregnant and nonpregnant groups in this respect.

Our study was limited by its retrospective character and its low statistical power, relative to the literature [14]. Nevertheless, our random choice of the embryo transfer day enabled us to obtain two demographically similar populations. We excluded cases in which the serum progesterone level was $>1.5 \mathrm{ng} / \mathrm{ml}$, which probably impacted the pregnancy rates. Likewise, the high incidence of "freeze-all" cycles in each group decreased the pregnancy rate per retrieval, and prompted us to only consider the pregnancy rate per transfer. The subsequent transfer of frozen embryos should result in even higher cumulative pregnancy rates. Lastly, our use of the same quality-controlled progesterone assay throughout our study minimized the variability in the concentration data. However, inter-assay differences are frequent, and so our results may differ from those of other studies.

\section{Conclusions}

Our present results showed that clinical pregnancy and live birth rates are significantly higher after blastocyst transfer than after cleaved embryo transfer in a general IVF/ICSI population but not in a selected "top cycle") population. One of the predictive factors for pregnancy was the serum progesterone level on the eve of the trigger day and on the day itself, which was significantly lower in the subgroups of women who became pregnant. In our study, the selection of "top cycles" reduced the 
impact of an elevated serum progesterone level on the trigger day, likely because of the good embryo quality that compensates the advance of luteal endometrial maturation associated with the premature elevation of the progesterone. We therefore recommend blastocyst transfer (or, for "top cycles", cleaved embryo transfer) in women with a serum progesterone level $<1 \mathrm{ng} / \mathrm{ml}$ on the trigger day. Further clinical, histological and genomic/ proteomic studies will be required to better understand the impact of low serum progesterone levels on pregnancy rates [56].

\begin{abstract}
Abbreviations
AMH: Anti-Müllerian hormone; ART: Assisted reproductive technology; BMI: Body mass index; 95\%Cl: Confidence interval at 95\%; CP: Clinical pregnancy; D2, D3, D5, D6: day 2, 3, 5 or 6; E2: Estradiol; FSH: Follicle stimulating hormone; GnRH: Gonadotropin releasing hormone; hCG: Human chorionic gonadotropin; hMG: Human menopausal gonadotropin; ICSI: Intracytoplasmic sperm injection; IVF: In vitro fertilization: IR: Implantation rate; LH: Luteinizing hormone; NS: Not significant; O: Oocyte; OP: Ongoing pregnancy; OR: Odd-ratio; P: Progesterone; 2 PN: Two pronuclei; P:E2: Progesterone to estradiol ratio; PFI: Progesterone to follicle index; POI: Progesterone to oocyte index; ROC: Receiver operating curve; SD: Standart deviation; WHO: World Health Organization
\end{abstract}

\section{Acknowledgements}

The authors thank David Fraser for their comments, suggestions and critical reading of the manuscript.

\section{Authors' contributions}

P M: substantial contributions to the conception, design of the work, the acquisition, analysis and interpretation of data; have drafted the work or substantively revised it. S B: the acquisition of data AS J: substantial contributions to the conception, design of the work; the acquisition, analysis and interpretation of data. JJ C: the acquisition of data. MT LM: substantial contributions to the conception, design of the work; the acquisition, analysis and interpretation of data. S R: the acquisition of data. C R: the acquisition of data. H D: the acquisition of data. A P: the acquisition of data. D B: the acquisition of data (Head of the Brest ART center). Each author have approved the submitted version and have agreed both to be personally accountable for the author's own contributions and to ensure that questions related to the accuracy or integrity of any part of the work, even ones in which the author was not personally involved, are appropriately investigated, resolved, and the resolution documented in the literature.

\section{Funding}

Not applicable.

\section{Availability of data and materials}

The material contained in this manuscript has not been published, has not been submitted or is not being submitted elsewhere.

The datasets used and/or analysed during the current study are available from the corresponding author on reasonable request.

\section{Declarations}

\section{Ethics approval and consent to participate}

All the couples have signed consent to the infertility treatment. Given that the couples had already consented (non opposition) to exploitation of their personal medical data for research purposes and in line with the French legislation on studies of routine medical care (Loi n78-17 du 6 janvier 1978 modifiée en 2004 relative à l'informatique, aux fichiers et aux libertés: For all research involving human participants, informed consent to participate in the study should be obtained from participants (or their parent or legal guardian in the case of children under 16), approval by an independent ethics committee was not required (Ethic committee report of Brest university hospital, 2019).
The consents of each couple are available in their medical record and with the corresponding author.

\section{Consent for publication}

The manuscript has been read and approved by all authors.

\section{Competing interests}

The authors report no conflicts of interest in relation to the present study.

Received: 16 September 2020 Accepted: 26 April 2021

Published online: 06 May 2021

References

1. Zeghers-Hochschild F, Adamson GD, Dyer S, Racowsky C, de Mouzon J, Sokol $\mathrm{R}$, et al. The international glossary on infertility and fertility care. Hum Reprod. 2017;32:1786-801.

2. De Geyter C. More than 8 million babies born from IVF since the Worlof s first in 1978; 2018.

3. Baker VL, Luke B, Brown MB, Alvero R, Frattarelli JL, Usadi R, et al. Multivariate analysis of factors affecting probability of pregnancy and live birth with in vitro fertilization: an analysis of the Society for Assisted Reproductive Technology Clinic Outcomes Reporting System. Fertil Steril. 2010;94:1410-6.

4. Cabry-Goubet R, Lourdel E, Brzakowski M, Urrutiaguer-Grenier N, Brasseur F, Demailly $P$, et al. Pregnancy predictive factors in case of double embryo transfer during « top quality » attempts. Gynecol Obstet Fertil. 2013;41:168-72

5. Cabry-Goubet R, Boulard V, Lourdel E, Devaux A, Copin H, BelaischAllart J, et al. How present ART' results: questions' list to French ART professionals and application on Amiens' ART results. Gynecol Obstet Fertil. 2012;40:24-30,

6. Bourgain C, Devroey P. The endometrium in stimulated cycles for IVF. Hum Reprod Update. 2003:9:515-22.

7. Fanchin R, Ayoubi JM, Righini C, Olivennes F, Schönauer LM, Frydman R Uterine contractility decreases at the time of blastocyst transfers. Hum Reprod. 2001;16:1115-9.

8. Wang SS, Sun HX. Blastocyst transfer ameliorates live birth rate compared with cleavage-stage embryos transfer in fresh in vitro fertilization or interacytoplasmic sperm injection cycles: reviews and meta-analysis. Yonsei Med J. 2014;55:815-25.

9. Glujovsky D, Farquhar C, Quinteiro Retamar AM, Alvarez Sedo CR, Blake D. Cleavage stage versus blastocyst stage embryo transfer in assisted reproductive technology. Cochrane Database Syst Rev. 2016;6:CD002118. https://doi.org/10.1002/14651858

10. Merviel P, Evain-Brion D, Challier JC, Salat-Baroux J, Uzan S. The molecular basis of human implantation in humans. Zentralbl Gynakol. 2001;123:328-39.

11. World Health Organization. WHO laboratory manual for the examination and processing of human semen. 2010.

12. Terriou P, Sapin C, Giorgetti C, Hans E, Spach JL, Roulier R. Embryo score is a better predictor of pregnancy than the number of transferred embryos or female age. Fertil Steril. 2001;75:525-31.

13. Gardner DK, Lane M. Culture and selection of viable blastocysts: a feasible proposition for human IVF ? Hum Reprod Update. 1997;3:367-82.

14. Venetis CA, Kolibianakis EM, Bosdou JK, Tarlatzis BC. Progesterone elevation and probability of pregnancy after IVF: a systematic review and metaanalysis of over 60000 cycles. Hum Reprod Update. 2013;19:433-57.

15. Grin L, Mizrachi Y, Cohen O, Lazer T, Liberty G, Meltcer S, et al. Does progesterone to oocyte index have a predictive value for IVF outcome? A retrospective cohort and review of the literature. Gynecol Endocrinol. 2018;34:638-43.

16. Younis JS, Matilsky M, Radin O, Ben-Ami M. Increased progesterone/estradiol ratio in the late follicular phase could be related to low ovarian reserve in in vitro fertilization-embryo transfer cycles with a long gonadotropinreleasing hormone agonist. Fertil Steril. 2001;76:294-9.

17. Shufaro Y, Sapir O, Oron G, Ben Haroush A, Garor R, Pinkas H, et al. Progesterone-to-follicle index is better correlated with in vitro fertilization cycles outcome than blood progesterone level. Fertil Steril. 2015;103:669-74 e1-e3.

18. Bourdon M, Pocate-Cheriet $K$, de Bantel AF, Grzegorczyk-Martin $V$, Amar Hoffet A, Arbo E, et al. Day 5 versus day 6 blastocyst transfers: a 
systematic review and meta-analysis of clinical outcomes. Hum Reprod. 2019;34:1948-64.

19. Levi-Setti PE, Cirillo F, Smeraldi A, Morenghi E, Mulazzani GEG, Albani E. No advantage of fresh blastocyst versus cleavage stage embryo transfer in women under the age of 39: a randomized controlled study. J Assist Reprod Genet. 2018;35:457-65.

20. Demirel C, Aydogdu S, Ozdemir Al, Keskin G, Bastu E, Buyru F. Blastocyst transfer does not improve cycle outcome as compared to D3 transfer in antagonist cycles with an elevated progesterone level on the day of hCG. J Turk Ger Gynecol Assoc. 2017;18:133-8.

21. Van Vaerenbergh I, Fatemi HM, Blockeel C, Van Lommel L, In't Veld P, Schuit $\mathrm{F}$, et al. Progesterone rise on HCG day in GnRH antagonist/rFSH stimulated cycles affects endometrial gene expression. Reprod BioMed Online. 2011;22: 263-71.

22. Labarta E, Martinez-Conejero JA, Alama P, Horcajadas JA, Pellicer A, Simon C, et al. Endometrial receptivity is affected in women with high circulating progesterone levels at the end of follicular phase: a functional genomics analysis. Hum Reprod. 2011;26:1813-25.

23. Filicori M, Cognigni GE, Pocognoli P, Tabarelli C, Spettoli D, Taraborrelli S, et al. Modulation of folliculogenesis and steroidogenesis in women by graded menotrophin administration. Hum Reprod. 2002;17:2009-15.

24. Xu B, Li Z, Zhang H, Jin L, Li Y, Ai J, et al. Serum progesterone level effects on the outcome of in vitro fertilization in patients with different ovarian response: an analysis of more than 10,000 cycles. Fertil Steril. 2012;97:1321-7 e.1-e.4.

25. Yang S, Pang T, Li R, Yang R, Zhen X, Chen X, et al. The individualized choice of embryo transfer timing for patients with elevated serum progesterone level on the HCG day in IVF/ICSI cycles: a prospective randomized clinical study. Gynecol Endocrinol. 2015;31:355-8.

26. Healy MW, Patounakis G, Connell MT, Devine K, DeCherney AH, Levy MJ, et al. Does a frozen embryo transfer ameliorate the effect of elevated progesterone seen in fresh transfer cycles? Fertil Steril. 2016;105:93-9 e1.

27. Al-Azemi M, Kyrou D, Kolibianakis EM, Humaidan P, Van Vaerenbergh I, Devroey $\mathrm{P}$, et al. Elevated progesterone during ovarian stimulation for IVF. Reprod BioMed Online. 2012;24:381-8.

28. Kyrou D, Al-Azemi M, Papanikolaou EG, Donoso P, Tziomalos K, Devroey P, et al. The relationship of premature progesterone rise with serum estradiol levels and number of follicles in GnRH antagonist/recombinant FSHstimulated cycles. Eur J Obstet Gynecol Reprod Biol. 2012;162:165-8.

29. Huang YH, Wang EY, Du QY, Xiong YJ, Guo XY, Yu YP, et al. Progesterone elevation on the day of human chorionic gonadotropin administration adversely affects the outcome of IVF with transferred embryos at different developmental stages. Reprod Biol Endoc. 2015;13:82.

30. Bodri D, Guillen JJ, Galindo A, Mataró D, Pujol A, Coll O. Triggering with human chorionic gonadotropin or a gonadotropin-releasing hormone agonist in gonadotropin-releasing hormone antagonist-treated oocyte donor cycles: findings of a large retrospective cohort study. Fertil Steril. 2009;91:365-71.

31. Kolibianakis E, Bourgain C, Albano C, Osmanagaoglu K, Smitz J, Van Steirteghem A, et al. Effect of ovarian stimulation with recombinant folliclestimulating hormone, gonadotropin releasing hormone antagonists, and human chorionic gonadotropin on endometrial maturation on the day of oocyte pick-up. Fertil Steril. 2002;78:1025-9.

32. Saadat P, Boostanfar R, Slater CC, Tourgeman OF, Stanczyk FZ, Paulson RJ. Accelerated endometrial maturation in the luteal phase of cycles utilizing controlled ovarian hyperstimulation: impact of gonadotropin-releasing hormone agonists versus antagonists. Fertil Steril. 2004;82:167-71.

33. Bosch E, Labarta E, Crespo J, Simón C, Remohí J, Jenkins J, et al. Circulating progesterone levels and ongoing pregnancy rates in controlled ovarian stimulation cycles for in vitro fertilization: analysis of over 4000 cycles. Hum Reprod. 2010;25:2092-100.

34. Corti L, Papaleo E, Pagliardini L, Rabellotti E, Molgora M, La Marca A, et al. Fresh blastocyst transfer as a clinical approach to overcome the detrimental effect of progesterone elevation at hCG triggering: a strategy in the context of the Italian law. Eur J Obstet Gynecol Reprod Biol. 2013;171:73-7.

35. Venetis CA, Kolibianakis EM, Bosdou JK, Lainas GT, Sfontouris IA, Tarlatzis BC, et al. Estimating the net effect of progesterone elevation on the day of hCG on live birth rates after IVF: a cohort analysis of 3296 IVF cycles. Hum Reprod. 2015;30:684-91.

36. Griesinger G, Mannaerts B, Andersen CY, Witjes H, Kolibianakis EM, Gordon K. Progesterone elevation does not compromise pregnancy rates in high responders: a pooled analysis of in vitro fertilization patients treated with recombinant follicle-stimulating hormone/gonadotropin-releasing hormone antagonist in six trials. Fertil Steril. 2013;100:1622-8 e1-e3.

37. Fanchin R, Righini C, Olivennes F, Ferreira AL, de Ziegler D, Frydman R. Consequences of premature progesterone elevation on the outcome of in vitro fertilization: insights into a controversy. Fertil Steril. 1997;68:799-805.

38. Requena A, Cruz M, Bosch E, Meseguer M, García-Velasco JA. High progesterone levels in women with high ovarian response do not affect clinical outcomes: a retrospective cohort study. Reprod Biol Endocrinol. 2014;12:69.

39. Santos-Ribeiro S, Polyzos NP, Haentjens P, Smitz J, Camus M, Tournaye H, et al. Live birth rates after IVF are reduced by both low and high progesterone levels on the day of human chorionic gonadotrophin administration. Hum Reprod. 2014;29:1698-705.

40. Wang A, Santistevan A, Hunter Cohn K, Copperman A, Nulsen J, Miller BT, et al. Freeze-only versus fresh embryo transfer in a multicenter matched cohort study: contribution of progesterone and maternal age to success rates. Fertil Steril. 2017;108:254-61 e4.

41. Papanikolaou EG, Kolibianakis EM, Pozzobon C, Tank P, Tournaye H, Bourgain $C$, et al. Progesterone rise on the day of human chorionic gonadotropin administration impairs pregnancy outcome in day 3 singleembryo transfer, while has no effect on day 5 single blastocyst transfer. Fertil Steril. 2009;91:949-52.

42. Papanikolaou EG, Pados G, Grimbizis G, Bili E, Kyriazi L, Polyzos NP, et al. GnRH-agonist versus GnRH-antagonist IVF cycles: is the reproductive outcome affected by the incidence of progesterone elevation on the day of HCG triggering ? A randomized prospective study. Hum Reprod. 2012;27:1822-8.

43. Vanni VS, Somigliana E, Reschini M, Pagliardini L, Marotta E, Fausili S, et al. Top quality blastocyst formation rates in relation to progesterone levels on teh day of oocyte maturation in GnRH antagonist IVF/ICSI cycles. PLOS. 2017. https://doi.org/10.1371/journal.pone.0176482.

44. Shapiro BS, Daneshmand ST, Restrepo H, Garner FC, Aguirre M, Hudson C. Matched-cohort comparison of single-embryo transfers in fresh and frozenthawed embryo transfer cycles. Fertil Steril. 2013;99:389-92.

45. Healy MW, Yamasaki M, Patounakis G, Richter KS, Devine K, DeCherney AH, et al. The slow growing embryo and premature progesterone elevation: compounding factors for embryo-endometrial asynchrony. Hum Reprod. 2017;32:362-7.

46. Hill MJ, Royster GD, Healy MW, Richter KS, Levy G, DeCherney AH, et al. Are good patient and embryo characteristics protective against the negative effect of elevated progesterone level on the day of oocyte maturation? Fertil Steril. 2015;103:1477-84 e1-e5.

47. Kolibianakis EM, Venetis CA, Bontis J, Tarlatzis BC. Significantly lower pregnancy rates in the presence of progesterone elevation in patients treated with GnRH antagonists and gonadotrophins: a systematic review and meta-analysis. Curr Pharm Biotechnol. 2012;13:464-70.

48. Devroey P, Pellicer A, Nyboe Andersen A, Arce JC. Menopur in GnRH antagonist cycles with single embryo transfer trial group. A randomized assessor-blind trial comparing highly purified hMG and recombinant FSH in a GnRH antagonist cycle with compulsory single-blastocyst transfer. Fertil Steril. 2012;97:561-71.

49. Lee VC, Li RH, Chai J, Yeung TW, Yeung WS, Ho PC, et al. Effect of preovulatory progesterone elevation and duration of progesterone elevation on the pregnancy rate of frozen-thawed embryo transfer in natural cycles. Fertil Steril. 2014;101:1288-93.

50. Santos-Ribeiro S, Racca A, Roelens C, De Munck N, Mackens S, Drakopoulos $P$, et al. Evaluating the benefit of measuring serum progesterone prior to the administration of HCG: effect of the duration of late-follicular elevated progesterone following ovarian stimulation on fresh embryo transfer live birth rates. Reprod BioMed Online. 2019;38:647-54.

51. Lai TH, Lee FK, Lin TK, Horng SG, Chen SC, Chen YH, et al. An increased serum progesterone-to-estradiol ratio on the day of human chorionic gonadotropin administration does not have a negative impact on clinical pregnancy rate in women with normal ovarian reserve treated with a long gonadotropin releasing hormone agonist protocol. Fertil Steril. 2009;92:508-14.

52. Lee FK, Lai TH, Lin TK, Horng SG, Chen SC. Relationship of progesterone/estradiol ratio on day of hCG administration and pregnancy outcomes in high responders undergoing in vitro fertilization. Fertil Steril. 2009;92:1284-9. 
53. Sharma V, Whitehead M, Mason B, Pryse-Davies J, Ryder T, Dowsett M, et al. Influence of superovulation on endometrial and embryonic development. Fertil Steril. 1990;53:822-9.

54. Golbasi H, Ince O, Golbasi C, Ozer M, Demir M, Yilmaz B. Effect of progesterone/estradiol ratio on pregnancy outcome of patients with high trigger-day progesterone levels undergoing gonadotropin-releasing

hormone antagonist intracytoplasmic sperm injection cycles: a retrospective cohort study. J Obstet Gynaecol. 2019;39:157-63.

55. Hugues JN. Impact of 'LH activity' supplementation on serum progesterone levels during controlled ovarian stimulation: a systematic review. Hum Reprod. 2012;27:232-43.

56. Haouzi D, Dechaud H, Assou S, De Vos J, Hamamah S. Insights into human endometrial receptivity from transcriptomic and proteomic data. Reprod BioMed Online. 2012;24:23-34.

\section{Publisher's Note}

Springer Nature remains neutral with regard to jurisdictional claims in published maps and institutional affiliations.

Ready to submit your research? Choose BMC and benefit from:

- fast, convenient online submission

- thorough peer review by experienced researchers in your field

- rapid publication on acceptance

- support for research data, including large and complex data types

- gold Open Access which fosters wider collaboration and increased citations

- maximum visibility for your research: over $100 \mathrm{M}$ website views per year

At BMC, research is always in progress.

Learn more biomedcentral.com/submissions 